\title{
Bandwidth-efficient correlative trellis-coded modulation schemes
}

\section{Doctoral Thesis}

Author(s):

Ramseier, Stefan

Publication date:

1991

Permanent link:

https://doi.org/10.3929/ethz-a-000599746

Rights / license:

In Copyright - Non-Commercial Use Permitted 
Diss. ETH $\mathrm{E}$ A

Diss ETH No. 9502

\title{
Bandwidth-Efficient Correlative Trellis-Coded Modulation Schemes
}

A dissertation submitted to the

\author{
SWISS FEDERAL INSTITUTE OF TECHNOLOGY \\ ZÜRICH \\ for the degree of \\ Doctor of Technical Sciences
}

presented by

STEFAN RAMSEIER

dipl. El. Ing. ETH

born April 26, 1961

citizen of Luzern LU

accepted on the recommendation of

Prof. Dr. F. Eggimann, referee

Prof. Dr. S.G. Wilson, co-referee

Zürich, 1991

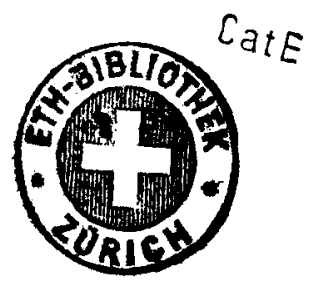




\section{Abstract}

A novel digital modulation scheme is proposed that allows to increase the data rate compared to uncoded modulation when the out-of-band power is fixed. If the data rate remains unchanged, this corresponds to a bandwidth reduction that is achieved by shaping the signal spectrum by the introduction of correlation in the transmitter. This correlation has to be resolved in the receiver by a maximum likelihood sequence estimator. Since the sequence of transmitted symbols can be represented by a trellis, this modulation scheme is called correlative trellis coded modulation (C-TCM). The transmitter is first optimized with respect to bandwidth-efficiency, i.e. it is designed to minimize the resulting out-of-band power. Where possible, a secondary optimization with respect to power-efficiency is performed, such that the signal-to-noise ratio required at the receiver to guarantee a certain error rate is minimum.

The optimization shows that for an encoder with memory one the well-known modulation schemes duobinary and dicode are optimum. The mappers that lead to a minimum average or peak power are presented.

The method derived for the optimization of the transmitter is applicable for any number of delay cells. In this report we present results for encoders with up to five delay cells, where new modulation schemes with time-limited and Nyquist pulse shaping filters are found. It is shown that the optimum transmitters can also be represented as partial response systems.

Considering the power-efficiency of the C-TCM scheme, it is shown that the remarkable increase of data rate of up to $300 \%$ compared to uncoded quaternary modulation is realized at the cost of about $1.5 \mathrm{~dB}$ additional signal power per delay cell. Comparing C-TCM with uncoded M-ary quadrature amplitude modulation, however, C-TCM allows to increase the data rate by up to $0.5 \mathrm{bit} / \mathrm{s} / \mathrm{Hz}$ for a given performance or to reduce the signal power by about $1 \mathrm{~dB}$ for a given data rate. 


\section{Kurzfassung}

Ein neuartiges digitales Modulationsverfahren wird beschrieben, das die Erhöhung der Datenrate gegenüber uncodierter Modulation erlaubt, wenn die Ausserbandleistung festgehalten wird. Dies entspricht einer Bandbreitenreduktion bei konstanter Datenrate, die dadurch erreicht wird, indem im Sender das Signalspektrum durch Einführen von Korrelation geformt wird; diese Korrelation muss im Empfänger mit Hilfe eines Maximum Likelihood Sequenzschätzers wieder rückgängig gemacht werden. Da die Funktion des Senders mit einem Trellis beschrieben werden kann, wird dieses Verfahren Korrelative Trelliscodierte Modulation (C-TCM) genannt. Zuerst wird der Sender bezüglich Bandbreiteneffizienz optimiert, d.h. er wird so gewählt, dass die Ausserbandleistung minimal wird. Wo möglich wird eine zweite Optimierung bezüglich Leistungseffizienz durchgeführt, damit das Signal/Rauschleistungsverhältnis am Empfänger, das zum Erreichen einer bestimmten Fehlerrate notwendig ist, minimal wird.

Die Optimierung zeigt, dass für Sender mit Gedächtnis 'eins' die bekannten Modulationsarten duobinär und dicode optimal sind. Für diesen Fall werden die Mapper, die zu einer minimalen mittleren oder Spitzenleistung führen, dargestellt.

Die Methode zur Optimierung des Senders gilt für eine beliebige Anzahl von Verzögerungselementen. In diesem Bericht präsentieren wir Resultate für Sender mit zwei bis fünf Verzögerungselementen, die neue Modulationsarten mit zeitbegrenzten und Nyquist-Pulsformungsfiltern darstellen. Es wird gezeigt, dass die optimalen Sender auch als Partial Response Systeme dargestellt werden können.

Beim Betrachten der Leistungseffizienz von C-TCM wird klar, dass die bemerkenswerte Erhöhung der Datenrate von bis zu $300 \%$ gegenüber uncodierter vierwertiger Modulation mit einem Verlust von etwa $1.5 \mathrm{~dB}$ Signalleistung pro Verzögerungselement erkauft wird. Wenn C-TCM hingegen mit uncodierter M-wertiger Quadraturamplitudenmodulation verglichen wird, zeigt sich, dass mit C-TCM die Datenrate bei gleichbleibender Signalleistung um bis zu $0.5 \mathrm{bit} / \mathrm{s} / \mathrm{Hz}$ erhöht, oder die Sendeleistung bei gleichbleibender Datenrate um etwa $1 \mathrm{~dB}$ verringert werden kann. 